\title{
Moderating Poverty: The Role of Remittances from Migration in Botswana
}

\author{
Eugene K. Campbell*
}

\begin{abstract}
This study examines internal labour migration of Botswana citizens and their remittance behaviour. Though international remittance is among topical global issues, it does not appear to contribute much currently towards national development in Botswana. About twenty-five years ago remittances from internal migration had no impact on poverty. This study indicates that the situation has not changed. The new economic theory of labour migration is addressed within a theoretical framework. From primary data, the level of poverty is measured and factors influencing remittances are examined. Following this is an examination of the impact of remittances on poverty. The results indicate that migrants maintain links with their home-based households through remittances in cash and goods. This is generally done in order to reduce poverty, especially in rural areas. There is considerable variation in the extent to which remittances are appreciated as a reliable means of subsistence in the household. Regression results reveal that economic and social factors are related with remittances from migrants. However, the remittances do not have a significant moderating effect on poverty in Botswana. While female-headed households dominated among those that were transitorily poor, there is no evidence that this is the case among those that lived in extreme poverty. Policy implications are addressed.
\end{abstract}

\section{Résumé}

Cette étude examine la migration interne de travailleurs Botswanais et leurs comportements en matière d'envoi d'argent. Même si les envois de fonds internationaux constituent une question d'actualité à l'échelle mondiale, il est

* Eugene K. Campbell PhD is in the Department of Population Studies, University of Botswana, P.O. Box UB 70075, Gaborone, Botswana.

E-mail: Campbell@mopipi.ub.bw 
impossible de dire qu'ils contribuent actuellement, de façon considérable, au développement national du Botswana. Il y a près de vingt-cinq ans, les envois d'argent effectués par des émigrés sur le plan national n'avaient aucun impact sur la pauvreté. L'étude révèle que la situation n'a pas évolué du tout. La nouvelle théorie économique relative à la migration de la main-d'œuvre est également abordée à partir d'une base théorique dans ce document. A l'aide de données de base primaires, le niveau de la pauvreté est mesuré et les facteurs qui influent sur les envois d'argent sont également examinés. L'auteur s'est également intéressé à l'impact des opérations d'envois d'argent/d'autres colis sur la pauvreté, ce qui a permis de se rendre compte que les immigrés entretiennent leurs liens avec les membres de leur famille restés au pays (d'origine) à l'aide des envois de fonds ou d'autres biens. Ils le font surtout pour aider à lutter contre la pauvreté, notamment en milieu rural. La façon dont les remises de fonds ou d'autres biens sont perçues comme de moyens sûrs de subsistance pour les ménages varie considérablement. Les résultats de régression montrent que des facteurs économiques et sociaux sont liés aux envois effectués par les immigrés. Cependant, les envois ne contribuent pas, de façon considérable, à la réduction de la pauvreté au Botswana. Si le nombre de ménages dirigés par des femmes était plus élevé parmi ceux considérés comme transitoirement pauvres, rien ne prouve que ceci est valable pour les ménages vivant dans une pauvreté extrême. Les implications des politiques sont également traitées dans le document.

\section{Introduction}

Increasing attention is been paid to migration as a survival strategy of the poor. But given the effects of globalization and the huge amount of money remitted each year the focus of research has shifted towards the dynamics of poverty and remittances within the framework of international migration. In Botswana, where emigration of skilled citizens is just beginning, it is expedient to examine the dynamics between remittances and internal migration to determine the potential of Batswana (citizens of Botswana) to remit. Largely as a result of economic factors, internal migration has increased remarkably since the country attained independence in 1966. Much of these movements were designed to reduce poverty in rural households. Voluntary labour migration is popularly perceived as a response to the economic gap between rural and urban centres. Whether migration is motivated by rural/urban income differentials (Todaro 1969; Harris and Todaro 1970); labour demand, income risk reduction (Stark and Levhari 1982) or social security mechanisms (Schrieder and Knerr 2000), the major driving force in migration decisions is the development of migrants and members of their families. To assist the achievement of this goal, money and goods are remitted by migrants to households (or families) at the origin. In Botswana, internal and international 
migrations have historically been perceived as a significant method of minimizing income risk and poverty.

The economic and settlement policies of the national government from 1966 contributed considerably in creating employment opportunities that enhanced internal labour migration. Households used these opportunities to send young men and women out to work (Lucas 1982) and these migrants assisted the families at home largely through remittances. The national education policy (Botswana 1994) provided additional opportunity to rural families to maximize remittances from their educated children. This paper addresses voluntary labour migrants and their links with families (i.e. households) at home. It is primarily designed to examine the factors that influence the receipt of remittance by households and to determine the effect of remittance on poverty reduction in households. Recognizing that the utility of remittance is best obtained from the recipient, this paper addresses this subject from the perspective of households at the origin. Before 1970, when poverty was rife and education levels very low in Botswana, emigration to South Africa was an important means of moderating poverty. But the situation has changed remarkably since then. With one of the best economies in Africa and a high level of education, internal migration in Botswana currently takes precedence over international migration.

\section{Theoretical considerations}

Remittances reflect human interaction and may be theoretically placed among the effects of social relations and economic behaviour (Mooney 2003). They play an important role in maintaining cultural, familial, kinship and community/ home links. Indeed, Gardner and Grillo (2002) have called attention to the contribution of traditional rituals to the continuity of migrants' affinity with home. Such rituals include periodic meetings of the extended family (migrant and non-migrant), and migrants who do not participate in them may not be appreciated as significant contributors to the wellbeing of households at home even if they do remit. In Sub-Saharan Africa, funerals frequently provide a justification for such meetings, especially to discuss inheritance issues. Nigerian funerals frequently involve conspicuous consumption, and this requires much human and financial contribution, much of which is remitted from within the country.

Notwithstanding the socio-cultural nature of remittances, they also serve to stratify receiving households according to their wealth. The new economic theory of labour migration (NELM) explains much of the relevance of remittances with economically disadvantaged households in sending areas. NELM considers the contribution of altruism and what Lucas and Stark (1985) 
refer to as self-interest in the desire to remit. Contrary to neoclassical theories, which associate migration with individual decisions, NELM argues that such decisions are actually taken by the household (Stark and Bloom 1985; Massey et al. 1993). The economic contribution of household members to migration costs partly explains the altruistic effect in migrants' decision to remit. NELM identifies remittance as a determinant of labour migration and also indicates that migration is selective by access to wealth (Gubert 2002). Here, the definition of wealth includes future income gained by educating children. Thus, households that have invested materially in educating their children would to a large extent receive more from such migrants where they remit (Mooney 2003). In effect, such households acquire sustained wealth by investing in the education of their children. It is therefore profitable to invest in children's education and, by implication, migration. However, until recently, primary and tertiary education in Sub-Saharan Africa was free or highly subsidized by several governments. Moreover, for many rural families, child fosterage and remittances contribute to the education of children (Schrieder and Knerr 2000; Alber 2003). Thus, the contribution of African rural families to income maximization by educating children is small compared to what it could have been if investment in education was at the level it is in developed countries.

Within the realm of neoclassical theories, Stark (1980) suggested that the lowest-income rural households received the most remittance because they sent most migrants to the city. This reaction was premised on a previously pessimistic observation by Rempel and Lobdell (1978) about the utility of remittances in sending areas. Contrary to Stark, these authors concluded that remittance does not contribute significantly to rural development. Instead return migration is the route through which migrants contribute to rural development. Drawing on evidence from Kenya, Stark (1980) maintained that remittance from urban areas actually contributes to reducing income inequality in rural areas. Joining the debate, Taylor (1999) cited studies that seem to support Rempel and Lobdell's view. He noted that migrants are incapable of converting 'savings into production' (Taylor 1999: 74). It was argued that remittances cannot stimulate economic growth where skilled labour is low, the economic structure lacks diversity, and 'there is (no) financial system capable of mopping up small amounts of savings from a wide variety of sources and channeling them to businesses willing and able to respond to a rising demand for their output' (Taylor 1999: 74, taken from Stahl and Habib 1991: 177).

However, Taylor conceded that the wide range of effects that remittances have on families and communities makes it difficult to test for macro- 
level effects from studies that merely describe how remittances are spent. After all, several studies support the NELM hypothesis that remittances are most effective in the poorest households and that they serve to ensure those that remain at the origin and reduce income risk (Taylor 1999; Gubert 2002). As Ahmed (2000) observed, some of the difficulties associated with analyzing the impact of remittances stem from including multiplier effects, which have greater implications on development demands than remittances could provide. Ahmed noted that very many positive effects could be observed by examining the immediate effect of remittances. After all, migrants remit mostly to satisfy short-term requirements in the household of origin. Those that are invested in long-term projects, such as buildings and farms, are made with a view towards individual or household development. They are therefore directly or indirectly associated with the migrant's return to the source. Thus, any reference to the impact of return migration on regional or national development, as Rempel and Lobdell (1978) suggested, may translate into positive impact of remittances on development.

Since the debate on the utility of remittances focuses on development, it is expedient to examine the factors that are considered in the measurement of development. For instance, it is apparent that the economic perspective of increased income inequality is that it is not a positive development (Taylor 1999). But the remittance effect should not be considered as negative simply because of its potential to stimulate income inequality. Realizing that remittances are made by individuals, independent of government's direct contribution, the focus of their impact should be within the household. From an international perspective, there are indications that diasporas contribute directly or otherwise to national development at home (Shain 2000), especially through 'brain circulation' effects. But the bulk of what is remitted is for individual or family benefit, and the total amount is difficult to obtain because of the variety of transfer methods used. If the unequal distribution of remittances in the rural area contributes to increased income inequality, this may reflect differential willingness of families to invest in children's education and migration. Improvement in education, health, housing and economic standards of families that receive remittances reflects positive effects of migration on development of the family. And if the returns to child education contribute to rising income inequality at the origin, this should serve to encourage less motivated families in the community to make similar investments in children.

From another perspective of NELM, the social network theory of remittances (Portes 1995) may be linked to the intergenerational wealth flows theory. This explains the influence of social and economic factors on fertility 
decisions, especially in developing countries (Caldwell 1978; Dow et al. 1994). In early transitional societies, it was strongly sanctioned and religiously expected that wealth would flow within the family through income transfers from younger to older generations. This situation was moderated considerably in the latter transition period largely through modernizing effects. Thus the transition to fertility decline was influenced partly by reduced intergenerational wealth flows as education of children increased childrearing costs to the extent that net financial benefit to parents approached zero. Parents' expectation of future economic rewards from children also holds within modernizing communities; and in the process of maximizing such rewards, parents would endeavour to provide children with the highest possible level of education. Likewise, households may contribute directly to poverty reduction by facilitating migration of eligible members. Where net reverse flow of remittance is negative (household to migrant minus migrant to household), the remittances received from such migrants assist in improving household incomes.

With increasing rural and national poverty in Sub-Saharan Africa since the 1980s, the preferences of educated migrants have been altered to the extent that they often decide to work in the city. Those who choose to assist their parents and families at the origin do so largely by remitting. Within contemporary African economic situations, remittance constitutes an important reason for migrating. Even among the educated and their daughters, marriage (bridewealth, etc.) does not quite deter intergenerational wealth flows. Depending on the financial agreement between spouses (Nwoye 2000), wives have freedom to remit. As Eloundou-Enyegue and Calves (2006) observed, educated African women have considerable ability to remit materially to their parents and family at the origin. However, the potential to receive remittances is often limited by existing social and economic conditions in many households.

\section{Methodology}

The data was obtained from a nationally representative survey of Botswana based on stratified and cluster sampling. The sample was selected to be proportional to population size for all relevant strata. Households were drawn from all major land use areas of the country including primary and secondary urban centres as well as major communal areas. This ensured that both sending and receiving areas of internal migration were included. Sample selection was done in two stages. The first stage was to randomly select district and urban areas out of the existing 36 census districts. This determined the number of primary sampling units (PSU) selected countrywide. Areas 
with very small populations were not selected as this was not cost effective. The second stage was random selection of enumeration areas (EA) from each of the rural and urban areas proportionate to the size of the PSU. A sample of 30 EA was randomly selected from each of the enumeration areas. All migrant households in each sample cluster were enumerated.

The 2001 national census population was used to select an initial sample of 1200 households. The total number of households selected in each of the census districts was proportionate to the size of the national households. For example, approximately $11.8 \%$ of the households were drawn from Gaborone as this was the proportion of households in the city in relation to the national population of households. The household data were provided by the household head. In very few cases a responsible adult served as proxy. Individual data were provided by the household member or (in the case of children and absentees) the household head or a knowledgeable person in the household.

SPSS was used to analyze the data. Logistic regression was applied to identify the factors that significantly influenced (1) receipt of remittance by households and (2) household poverty. The first response was obtained from the question, 'does a migrant worker send money home to this household?' The target response is Yes while No is the reference category. Yes and No were recoded to reflect 1 and 0 , respectively, in the SPSS system. Poverty was defined to reflect households that lived without cash, food, water, medical treatment/medicine, electricity and/or cooking fuel most of the time or always during the past year (12 months preceding the survey date). Households that never experienced being without these essential items or had experienced it once or occasionally were grouped into the reference category (recoded 0 ). Each item (cash food, etc.) was recoded 1.

In selecting the predictors that were included in the first analysis, the focus was to produce a model that was significant (see Pregibon 1981; Hosmer and Lemeshow 2000). It was decided that the most significant model obtained after the predictors were entered would determine the variables discussed in this paper. With respect to the determinants of remittance received, the independent economic variables are: Number of times household lived without cash (defined as never $=1$; once $=2$; several times $=3$; many times $=4$; always $=5$ ); Household borrowed money in past 12 months (yes $=1 ;$ no $=2)$; Household remitted to migrant (yes $=1$; no $=2)$; and Annual income (less than $\mathrm{P} 30,000=1 ; \mathrm{P} 30,000$ and over $=2$ ). Income includes total earnings from wages, formal and informal businesses, farms and pensions. The demographic variables are: Age (defined as $<45$ years $=1 ; 45+$ years $=2)$; Sex $($ male $=1$; female $=2)$; Education (none and primary $=1$; secondary and tertiary $=2$ ); Marital status (married $=1$; single [includes 
separated, divorced and cohabiting] $=2$ ); and, having observed the effect of including international migration in this analysis, we included internal/ international migrant (internal $=1$; international $=2$ ). This variable is better than another that represented urban/rural region (REGION). The sociocultural variables are: Frequency of migrant's home visits (monthly $=1$; once in three months $=2$; once in six months $=3$; once a year $=4$ ); Household member visit migrant (yes $=1$; no $=2$ ); and language spoken at home (Setswana $=1 ;$ Kalanga $=2$ ). In each analysis, the last category is the reference category.

\section{Definition of concepts}

A migrant is a person who moved from one region (district) in Botswana to another to work or seek work.

Extreme poverty is sustained poverty throughout the study year, and transitory poverty is a temporary state of poverty that occurs among people whose annual income is above poverty level.

A household consists of people who share food from a common source, sleep in the same house or compound at least 15 days in the past year and share in a common resource pool. Unlike the de jure definition of a household, which excludes migrants from the home household (see Sanni 2006), the culture of Batswana permits their inclusion in the household (see Lucas 1982; Izzard 1985).

\section{Results}

\section{Household characteristics}

The actual sample was 1160 households comprising a total of 6744 persons, and average household size was 5.8 persons. The mean age of the population was 29 years and the sex ratio was low (94 males to 100 females). The majority (88\%) of those who were five years of age and over were educated. Most of them had been to primary and secondary school (54\% and 28\%, respectively) while $18 \%$ had achieved tertiary education, with half having studied in a university. Employment rate (excluding students) was $72 \%$, and a considerable proportion (44\%) of those employed were professional, administrative and managerial officers or self-employed business persons. Most of the others were employed in sectors that did not require much skill (e.g. manual, domestic, service, mine, agricultural, fishing and security workers as well as hawkers). The average (mean) annual income was $\mathrm{P} 22,706$, which is about what the average citizen earned in 2001 (see Botswana 2003). From an economic perspective, this implies considerable poverty within the study population. 


\section{Poverty and its measurement}

Though there is evidence of poverty in Botswana, its economy and social policies have produced a population with a much better standard of living than obtains in most Sub-Saharan African countries. According to the national government, the current poverty rate is $23 \%$, an increase of 3 percentage points from 1994 (Botswana 2007; Gaolathe 2007). However, since 2000, the government has found it difficult to increase employment nationally (Anonymous 2005). In a paper presented at the Review of the National Population Policy Delivery in June 2007, H.M. Yousif revealed that unemployment had increased since the 1990s especially among the youth. The Household Income and Expenditure Survey in 2002/03 reported a national unemployment rate of $24 \%$, with school leavers between 15 and 24 years old being the worst affected (Botswana 2007). The observations about unemployment in Botswana and the higher poverty figures provided by other sources challenge the government's poverty rate. The Botswana Institute for Development Policy Analysis estimated that in 1993/94, 47\% of Botswana citizens lived below the poverty line (BIDPA 1997) and it was argued that this figure reflected a substantial decline in poverty since 1985/86. But BIDPA's method of measuring poverty is basically economic, which is restrictive, given its poor treatment of social factors that contribute significantly to human development.

Probably mindful of this, Mattes et al. (2003) developed the lived poverty index (LPI), which was applied to data from surveys of the living conditions of people in southern Africa in 2000. It implied cognizance of the hierarchy of needs by Maslow (1943) and Sen's (1999) view that poverty should be measured from the standpoint of access to basic needs. Mattes et al. (2003) found that citizens of Botswana and South Africa enjoyed the best standard of living in southern Africa. Among the merits of the LPI method are that it is simple, it provides a direct measure of people's access to basic needs and it considers the multi-dimensionality of human wellbeing. This method was applied to the data on which the current study is based, using twenty-one questions. The questions asked how frequently households were forced to live without basic necessities (such as food, clean water, etc.) as well as fear of crime, domestic violence, etc. (see Table 1). For example, 'how often have you or your family gone without food, etc.?' and 'how often have you or your family feared crime, etc. in your home?' In the first question, 'food' was subsequently replaced by 'clean water', 'medical treatment', etc. while in the second question 'crime' was subsequently replaced by 'housebreaking', 'physical assault', etc.. 
Table 1: Lived poverty index (LPI) for basic necessities, fear, etc.

\begin{tabular}{|c|c|c|}
\hline Unit of Index & LPI & $\mathrm{N}$ \\
\hline Food & 1.05 & 1135 \\
\hline Clean water & 0.86 & 1152 \\
\hline Medicine & 0.80 & 1131 \\
\hline Electricity & 1.59 & 984 \\
\hline Fuel & 1.04 & 1138 \\
\hline Cash income & 1.46 & 1136 \\
\hline Crime & 1.30 & 1143 \\
\hline Housebreaking & 0.84 & 1146 \\
\hline Physical assault & 0.66 & 1144 \\
\hline Domestic violence & 0.60 & 1139 \\
\hline Communal violence & 0.61 & 1137 \\
\hline Fear of being raped & 0.53 & 1143 \\
\hline Fear of being murdered & 0.53 & 1127 \\
\hline Witchcraft & 0.94 & 985 \\
\hline Livestock stolen & 0.71 & 1127 \\
\hline Land dispute & 0.60 & 1137 \\
\hline Serious illness & 0.91 & 1147 \\
\hline Young child dies & 0.67 & 1142 \\
\hline Young adult dies & 0.68 & 1144 \\
\hline Drought & 0.72 & 1136 \\
\hline Flood & 0.55 & 1141 \\
\hline Total & 0.84 & 1125 \\
\hline
\end{tabular}

LPI scores range from 0 to $4(0=$ zero poverty and $4=$ extreme poverty). The means of the poverty ratios for food, etc. were computed from grouped poverty levels $(0-1,1-2,2-3,3-4)$ as $m=\Sigma \mathrm{fx} / \mathrm{n}$. For example, the index for food was computed as $\Sigma(720(0.5), 220(1.5), 182(2.5), 13(3.5)) / 1135$. Table 
1 shows the computed LPI of the basic needs and fear or experience of negative events. With the exception of fear of crime, much of the hindrance to attaining high living standards is apparently influenced by access to basic needs. Medical treatment and clean water are the only two basic items that have LPI less than 1. Much of the credit for good access to medical treatment goes to the national government for its vigorous implementation of thehealth policy that was designed to improve the state of wellness of the population (Botswana 1991). Electricity and cash income seem to be the most troublesome obstacles to living above poverty level. Crime has increased in Botswana since 1990; and while this is largely an effect of development, it has been frequently associated with illegal immigration, especially of Zimbabweans (Daily News 2000; 2001). Where basic needs only are considered, the LPI is 1.13 (i.e. $\Sigma(1.05,0.86,0.80,1.59,1.04,1.46) / 6$. This is lower than Mattes et al.'s (2003) estimate (1.98) for Botswana in 2000 (at the time the lowest in southern Africa). When fear (related to crime, violence, etc.) was included among the units of analysis, the overall LPI dropped to 0.84 , implying a good level of security among the study population.

Table 2 indicates that the majority (63\%) of households were never forced to live without sufficient food during the twelve months preceding August 2004. Seven percent always lived without sufficient food throughout this period. A much higher proportion of households ( $77 \%$ and $79 \%$, respectively) had never been without clean water and medicine/medical treatment. Electricity ranked lowest among the basic necessities that the population had access to. However, given the financial cost versus utility function of this power source to rural populations' preferences for cheaper alternative sources of fuel (such as candles, firewood, paraffin and gas), the satisfaction derived from using non-electrical appliances probably puts the wellbeing of households higher than the figures suggest. This position tends to receive support from the observation that only $7 \%$ of households always lacked sufficient cooking fuel during the reference period. Cash income ranked lowest among the basic factors that households never lacked.

A better understanding of poverty levels in Botswana was obtained from an examination of the dummy variables that were created from six basic needs of our sample population (i.e. cash, food, water, medicine, electricity and fuel) for use as response variables in regression analysis. Each variable represents poverty where people lived without these basic factors most of the time and always. 
Table 2: Percentage of household members' experience of having gone without food, etc.

Unit of basic necessity Never Just once or Many times/ Always Total N Twice/Several times

\begin{tabular}{lccccc}
\hline Enough food to eat & 63.4 & 30.0 & 6.6 & 100.0 & 1136 \\
Enough clean water & 76.8 & 17.8 & 5.4 & 100.0 & 1142 \\
Medicine/medical & & & & & \\
treatment & 79.1 & 17.1 & 3.8 & 100.0 & 1132 \\
Electricity in the home & 55.1 & 13.8 & 31.1 & 100.0 & 984 \\
Enough cooking fuel & 65.1 & 27.6 & 7.3 & 100.0 & 1138 \\
Cash income & 45.5 & 36.8 & 17.7 & 100.0 & 1137 \\
\hline
\end{tabular}

From these variables a composite variable (POVERTY) was computed to represent the population that was not poor $(0)$ and those that were at a level of poverty (1 to 6). The six are cases where households lived without one or more of the six basic factors. Poverty was subsequently divided into $1=$ Transitory Poverty and 2-6 = Extreme Poverty. The results indicate that $48 \%$ of the population were not poor while $27 \%$ were transitorily poor and $25 \%$ were extremely poor. There was significant gender difference in the exposure to poverty $\left(\mathrm{X}^{2}=10.84, \mathrm{p}<.01\right)$. Table 3 shows a dominance of men among those that were not poor. However, substantially more women than men were transitorily poor. Contrary to general opinion that extreme poverty affects significantly more women than men in Botswana, the results suggest otherwise. The difference between extremely poor male-headed households and women-headed households is apparently not significant.

Table 3: Percentage distribution of people that were not poor and poor, by sex

\begin{tabular}{lcc}
\hline Level of poverty & Male & Sex \\
& & Female \\
\hline Not poor & 51.4 & 42.4 \\
Transitory poverty & 23.0 & 31.7 \\
Extreme poverty & 25.6 & 25.9 \\
Total & 100.0 & 100.0 \\
$\mathrm{~N}$ & 591 & 394 \\
\hline
\end{tabular}

$\mathrm{X}^{2}=10.836, \mathrm{p}<.01$ 


\section{Migration}

The study enumerated a total of 1377 internal labour migrants. The majority $(77 \%)$ of these had regular jobs, $17 \%$ were seasonal workers and the rest were unemployed. Most migrants had moved at least twice (i.e. from birthplace to place of previous residence and from previous residence to current place of residence). During the first move $82 \%$ were from rural areas; but during the second move, this proportion fell by ten percentage points. Much of the change in the pattern of internal migration may be attributed to increased urbanization. Before 1991, rural localities in Botswana were considered villages or large villages, depending on population size. By parliamentary Act, the large villages were reclassified as urban if, in addition to a threshold population of 5,000,75\% of the labour force was employed in non-agricultural sectors (Gwebu 2006). Almost half of the migrants went to the capital city (Gaborone). An additional 15\% went to Francistown (the second largest city in the country).

For a quarter of the migrants, family issues, such as fosterage and marriage, influenced migration from the birthplace. The economic factor was second among motivators of migration to urban areas, but was third where the destination was rural. Probably related to greater numbers of secondary and tertiary educational institutions in urban areas, relatively more migrants moved to urban than rural centres for educational reasons. Similarly, more migrants went to urban than rural centres for 'bright light' reasons (i.e. attraction of the city). During the second wave of migration, economic factors formed the primary motive for moving to urban and rural centres $(33 \%$ and $30 \%$, respectively). Family issues dropped to second place while living conditions was third. Differential preference for urban and rural areas was particularly evident where education and attraction of city were concerned. Twentynine percent of the population that was 15 years and over intended to migrate elsewhere in future.

\section{Remittances}

Many households depend partly on remittances in order to maintain a healthy state of economic wellbeing. Fully $71 \%$ of all household income was derived from wage work and income from informal trade and casual work. An additional $18 \%$ was obtained from remittances of money and goods from migrants and the rest was from other sources, including agriculture. Some $65 \%$ of migrants remitted, and the average (mean) amount of cash remitted during the twelve months before the survey was P1650. The peak frequency $(53 \%)$ of remittance was once a month, while $7 \%$ of migrants remitted at least twice a month, $16 \%$ did so once every three months, $12 \%$ more than twice in three months and a few (4\%) remitted once a year. Half of the 
migrants preferred to carry the money home personally. The post office and bank were the second and third most preferred mode of transfer. Almost everyone was consistent in using the most preferred money transfer method. This is largely because it was perceived to be highly reliable.

Migrants from rural areas apparently have a greater propensity to remit than those from urban areas $\left(\mathrm{X}^{2}=51.27, \mathrm{p}<0.001\right)$. Though the proportion $(58 \%)$ of migrants from rural areas exceeded that of urban areas by 16 percentage points, the difference among those who remitted was much greater (67\% rural versus 33\% urban). In both rural and urban areas there was no significant difference between the proportion of migrants who remitted less than P1000 and those who remitted P1000 or more $\left(X^{2}=1.21, p>0.05\right)$. Though males seemed to remit a little more than females, the difference was not significant $\left(X^{2}=1.36, p>0.05\right)$. Similarly, while migrants with secondary and tertiary education appeared to remit more than those with primary or no education, the difference was not significant $\left(\mathrm{X}^{2}=2.01, \mathrm{p}>0.05\right)$. The data also did not support the theory that educated migrants remit less frequently than less educated ones $\left(\mathrm{X}^{2}=1.23, \mathrm{p}>0.05\right)$. However, there was general agreement that migrants' remittances contribute much to the availability of basic necessities (food, cash, education, etc.) in the home-based household (see Table 4). Further analysis points toward this being stronger in rural than urban areas $\left(X^{2}=2.89, \mathrm{p}<0.01\right)$. Much less $(67 \%)$ expressed positive feelings about the general effect of migration in the household; $15 \%$ felt otherwise while the rest thought that labour migration made no significant difference to standard of living in the household.

Table 4: Importance of remittances to survival of household (percentage) regarding availability of basic items

\begin{tabular}{lccccc}
\hline \multicolumn{1}{c}{ Item } & Important & Neutral & $\begin{array}{l}\text { Not } \\
\text { important }\end{array}$ & Total & N \\
\hline Enough food to eat & 87.9 & 7.7 & 4.4 & 100.0 & 775 \\
Enough clean water & 75.3 & 12.3 & 12.4 & 100.0 & 775 \\
Medicine/medical treatment & 72.2 & 15.0 & 12.8 & 100.0 & 769 \\
Electricity & 75.1 & 10.9 & 4.0 & 100.0 & 675 \\
Enough cooking fuel & 82.4 & 10.6 & 7.0 & 100.0 & 771 \\
Cash income & 87.5 & 7.3 & 5.2 & 100.0 & 772 \\
Sending children to school & 78.2 & .3 & 14.5 & 100.0 & 757 \\
\hline
\end{tabular}


Though it is usually perceived that remittances move in the direction of migrant to household, it is not always so. A considerable amount of gross remittance is made by the household to migrants, especially those that are in school or looking for work. The average amount of money transferred by households to migrants during the year preceding the survey was P1289. Considering the amount remitted by migrants, it appears that the net remittance favours households. The highest average amount transferred then (P9398) was made by households that remitted money more than twice in three months, and the second highest occurred among those that remitted regularly on a monthly basis. Most of the remittances were sent by household heads or their spouses (56\% and $31 \%$, respectively). Two-thirds of the senders were female, thereby reflecting the remarkable economic role (and independence) of women in Botswana households. Many $(68 \%)$ of the recipients of these remittances were sons and daughters of household heads. Considering that a substantial proportion of household members left to work or look for work, it may be conjectured that these recipients were not only students, but also young labour migrants who were either unemployed or had not yet acquired enough to contribute to their parents' household income. Remittances from households to migrants were more frequently in the form of money $(57 \%$ of remitting households sent money) and food (36\%). Just over half of the households (52\%) sent these items once every six months or once a year.

\section{Multivariate analysis}

Table 5 shows the factors that influence receipt of remittance from migrants. Given the multicolinearity between income and education, an interaction term (education $\mathrm{x}$ income) was included in Model 1. But the model does not seem satisfactory, though the goodness of fit is significant. Hence, mindful that education may serve as a proxy for income (Ben-Porath 1973), it replaces the interaction term in the second model. This improves the model fitness and it is therefore preferred. Some results in the model are significant at .05 level and may be subject to type II error; but they are hereby assumed to be free of such error.

Model 2 indicates that households that lived without cash just once in the past year were four times more likely to receive remittances from migrants than those that always lived without cash. Also, those that lived without cash several times were five times more likely to receive remittances from migrants than those that always suffered the same fate. This implies that economic poverty does attract financial assistance through remittances but raises questions about its significance. The model also shows that households that borrowed money as a survival strategy during the twelve months preceding the survey were about two times more likely to receive remittances than 
those that did not borrow money. Considering that the poor tend to lack collateral for effective borrowing, it is possible that some households borrow on the strength of expected remittances.

Table 5: Odds ratios from logistic regression of remittance from migrant on demographic, economic and socio-cultural factors

\begin{tabular}{lll}
\hline \multicolumn{1}{c}{ Variable } & Model 1 & Model 2 \\
\hline Economic & & \\
Frequency living without cash & & \\
Never & 0.389 & $2.305^{*}$ \\
Just once & 1.095 & $4.378^{* * *}$ \\
Several times & 1.044 & $4.758^{* * *}$ \\
Many times & 0.522 & $2.539^{*}$ \\
Household remits to migrant & .478 & 1.358 \\
Household borrowed money & 1.263 & $1.920^{* *}$ \\
Demographic & & \\
Sex & 1.444 & 1.269 \\
Age & 0.478 & 0.915 \\
Marital status & 0.609 & 0.685 \\
Interaction term (income x education) & 0.895 & - \\
Education & - & $1.822^{*}$ \\
Internal migrant & $3.052^{*}$ & $4.076^{* *}$ \\
Socio-cultural & & \\
Frequency of migrant visit home & & 1.224 \\
Monthly & $7.386^{* * *}$ & $5.233^{* * *}$ \\
Once in three months & $3.672^{* *}$ & $2.878^{* *}$ \\
Once in six months & 1.277 & 1.431 \\
Household member visit migrant & $2.675^{* *}$ & $2.787^{* * *}$ \\
Language spoken at home & $2.967^{* * *}$ & \\
$\mathrm{~N}$ & 392 & \\
\hline
\end{tabular}


It is also observed that visitations by migrants and by household members to migrants influence the flow of remittance to the respective households, thereby supporting an observation, inter alia, that bringing remittances home is popular among migrants. Migrants who visited home every month were five times more likely to remit than those who visited home once a year. The corresponding odds ratio for those who visited home every three months was $2.88(\mathrm{p}<.01)$. Similarly, migrants who received visitors from the household were three times more likely to remit than those who were not visited by household member(s). The data also suggest that the likelihood of receiving remittances from internal migrants was four times greater than that of international migrants.

\section{The effect of remittance on poverty}

Given the theoretical link between remittance and poverty, we now examine the impact of remittances from migrants on poverty. The analyses commence with an investigation of the effect of remittances on access to the six basic items, i.e. cash, food, water, medical treatment/medicine, electricity and cooking fuel. Once more, education is used as a proxy for income because it produced a better model than when the interaction term (education $\mathrm{x}$ income) was included. Consideration of income here assumes that household annual expenditure was more or less proportional to household income. The results reveal that remittances from migrants do not have significant impact on poverty (see Table 6). However, with the exception of medical treatment/medicine, education above primary school level is apparently required to live above poverty. There are indications that living in rural areas enhances the chances of being poor. Apparently, borrowing money reduces the chances of being without cash many times or always.

With the composite variable as the response, Table 7 reveals the absence of significant influence of migrant remittances on aggregate poverty in Botswana. However, it does indicate that people with primary or no education are three times more likely than those with secondary and tertiary education to head poor households. Where migrants work on a seasonal basis, there seems to be less chances that the household would be poor. Male-headed households were less likely than female-headed ones to be poor (i.e. aggregated poverty). 


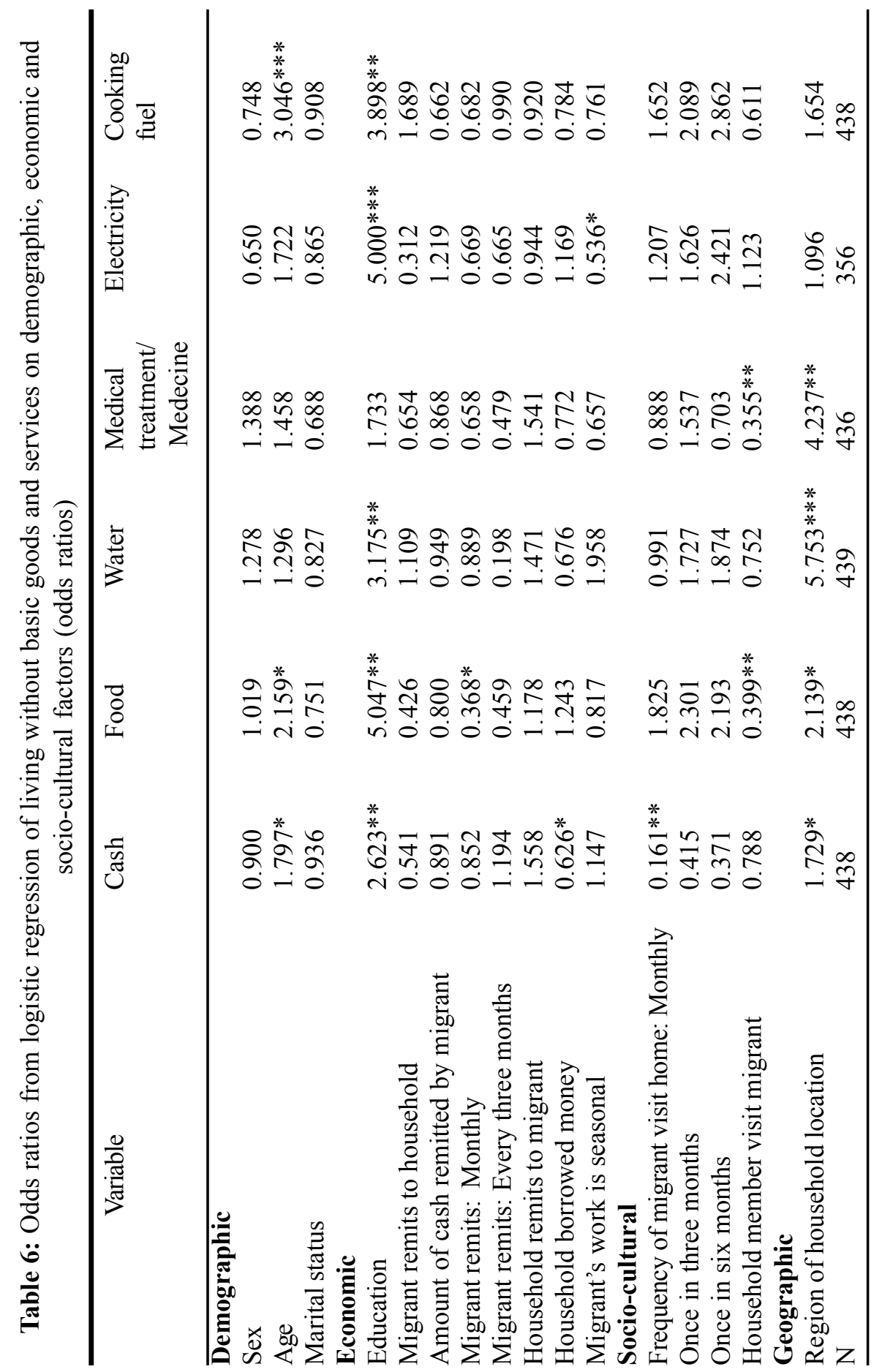


Table 7: Odds ratios from logistic regression of poverty on demographic, economic and socio-cultural factors

Variable

Aggregate poverty

Extreme poverty

(Transitory \& Extreme)

\section{Demographic}

Sex

Age

$0.447 * *$

0.900

Marital status

$1.865^{*}$

$2.461 * *$

Marital status

1.132

0.832

\section{Economic}

Education

Migrant remits to household

Amount of cash remitted by migrant

0.896

0.291

Migrant remits: Monthly

0.458

0.525

Migrant remits: Every three months

0.619

0.606

Household remits to migrant

1.340

1.746

Household borrowed money

1.051

0.864

Migrant's work is seasonal

$0.484 *$

1.103

\section{Socio-cultural}

Frequency of migrant visit home:

Monthly

0.714

0.570

Once in three months

0.853

Once in six months

Household member visit migrant

0.820

0.582

\section{Geographic}

Region of household 
Where extreme poverty was examined, the results in Table 7 reveal again the significant influence of education. Households with heads that had primary or no education were four times more likely to be extremely poor than those where the head was educated at secondary or more level. The indications again are that remittances do not have a significant impact on extreme poverty. Similarly, households were about two times more likely to experience extreme poverty

where the head was younger ( $<45$ years) than otherwise. The table also shows that rural households were twice as likely as urban ones to be in extreme poverty. It appears that the significant relationship between gender and household poverty obtains only within transitory poverty. Where extreme poverty is considered, women are apparently not more likely than men to head poor households.

\section{Discussion and policy implications}

Undoubtedly this study reveals that a systematic link exists between internal migrants and their families at home. But it raises questions about the importance of this link to especially rural households. The results of univatriate and bivariate analysis point toward Ahmed's (2000) observation that remittances have positive effects on the economic wellbeing of households. But the multivariate analysis indicates otherwise. Table 6 and 7 reveal that remittances currently have no significant influence on poverty (transitory and extreme) in Botswana. In other words, the ability of very poor households to lift themselves out of this state is not assisted by the remittances that migrants send. This conclusion is consistent with that of Lucas (1982) and seems to strengthen the observation (noted inter alia) by Rempel and Lobdell (1978).

The data that Lucas used was obtained about three decades ago (Botswana 1982) when income and educational levels were quite low and wages from work in South African mines were significantly higher than those in Botswana. Even so, Lucas reports that the amount of money remitted by migrants was still small after including the effect of mine workers' remittances. From a qualitative study Izzard (1985: 274) observed that 'rural women complained that the remittances they received were inadequate and irregular'. Table 5 in this paper indicates that internal migration now contributes more to remittances than international migration. This may be partly explained by the increasing number of highly educated citizens who hold senior administrative and professional positions in Botswanan towns and cities. Meanwhile relatively few Batswana professionals currently work outside the country and the number of people (mostly unskilled) working in South African mines has fallen considerably. From a peak of 18,079 Batswana 
mine workers in 1985, there were 6494 in 2000 (SAMP 2005). Much of the remittances that went from urban to rural areas recently were motivated by altruism as well as self-interest. While the magnitude of the two cannot be determined, it is likely that the difference between the two partly explains the insignificant impact of remittances. In view of this and Lucas's (1982) observation that remittances from migrants were quite low, it appears that the net effect of remittances from migrants was not enough to make a significant impact on poverty in rural areas. However, the expressed satisfaction that some households derived from migrants' remittance should not be overlooked. Poor households may likely have been worse off in the absence of remittance. What this study reveals is that remittances from migrants are not significantly high enough to help raise households out of poverty.

The proportion of this study's sample that lived in extreme poverty is more or less consistent with the government's figures for level of poverty in Botswana. However, bearing in mind the controversy related to measurement of poverty (see Aaberge and Mogstad 2007), the 25\% level of (extreme) poverty is considered tentative. In view of the feminization of poverty theory, our observation that female-headed households were more likely to be transitorily poorer than their male counterparts is consistent with other findings (see Akinsola and Popovich 2002). However, we find no evidence of gender difference in the experience of extreme poverty, and this requires some comment. Notwithstanding the methodology on which this finding was obtained, there is a good reason to retain it. Increasingly, questions are being raised about the reliability of the feminization of household poverty in developing countries (e.g. Buvini and Gupta 1997; Quisumbing et al. 2001; Medeiros and Costa 2006). From a study of ten developing countries (including Botswana), Quisumbing et al. (2001) found that while poverty exists more in female-headed than male-headed households in many developing countries the difference between these two groups of households is really not significant. In Botswana, three measures indicated that poverty was greater among malethan female-headed households, though the difference was insignificant. Chant (2007) further observed the appearance of a dominance of female-headed households among those that were not poor. Several cultural props that fuelled gender discrimination in Botswana have weakened considerably, partly owing to the government's educational policy and changes in fertility attitudes, which have significantly moderated preferences for sons.

\section{Policy implications}

The results point towards a need to review the poverty, education, employment, gender and urbanization policies in Botswana. However, our results on household poverty do not lend themselves easily to policy formulation be- 
cause the survey was designed to investigate poverty at a macro (household) level. As Fuwa (2000) noted, a micro-level investigation is required to fully understand the dynamics between individuals in the household in order to arrive at policy statements that would benefit governments in their quest to minimize poverty. In this regard, it would be premature to recommend policies from our observation that female-headed households experience extreme poverty as much as male-headed households. What this study brings out is the immediate need for further in-depth research in this area. While this could be costly, it is expedient to guide government and non-governmental organizations on where to focus future plans and projects that address poverty in Botswana.

It may be conjectured that the remittances do not assist in poverty alleviation partly because remitting is only one of many options available to households wishing to reduce poverty risk. As the results show, borrowing is also an option that households take (and there is no significant difference in the borrowing practices of the poor and those that were not poor). But apart from providing temporary relief from cash problems, it does not significantly influence poverty. The reality is that the government has provided its citizens with many poverty-alleviating options by establishing economic development agencies and programmes such as the Botswana Institute of Development and Policy Analysis, Botswana Productivity Centre and Citizen Entrepreneurial Development Agency (Matiage 2002). Given that the poor have limited access to personal and other loans, government interventions leave the public with few options lift themselves out of poverty from individual efforts. Owing to economic and other factors, there is a high preference among young professionals to emigrate to work in other countries (Crush 2006). This may, in future, provide substantial remittances to assist in moderating poverty in especially rural areas. Hence, now is the time for the government to consider policies that would attract remittances from its citizens who would have left the country to work elsewhere.

\section{References}

Aaberge, R. and Mogstad M., 2007, On the Definition and Measurement of Chronic Poverty, Discussion Paper No. 2659, Institute for the Study of Labor: Bonn.

Ahmed, I.I., 2000, 'Remittances and their economic impact in post-war Somaliland', Disasters 24: 380-389.

Akinsola, H.A. and Popovich, J.M., 2002, 'The quality of life of families of femaleheaded households in Botswana: A secondary analysis of case studies', Health Care for Women International 23: 761-772. 
Alber, E., 2003, Denying biological parenthood: fosterage in northern Benin, Ethnos 68:487-506.

Anonymous, 2005, 'Standards and Poor's Releases Botswana's 2005 Sovereign Credit Rating. A Bank of Botswana Press Release'. www.bankofbotswana.article.php

Ben-Porath, Y.,1973, 'Economic analysis of fertility in Israel: point and counterpoint', Journal of Political Economy 18: S202-233.

BIDPA, 1997, Study of Poverty and Poverty Alleviation in Botswana, Vol. 1, Government Printer: Gaborone.

Botswana, 1982, Migration in Botswana: Patterns Causes and Consequences, A National Migration Study, Government Printer: Gaborone.

Botswana, 1991, National Development Plan 7, 1991-1997, Government Printer: Gaborone.

Botswana, 1994, The Revised National Policy on Education, Government Printer: Gaborone.

Botswana, 2003, Labour Statistics 2001, Government Printer: Gaborone.

Botswana, 2007, 2002/03 Household Income and Expenditure Survey: Botswana, Government Printer: Gaborone.

Buvini, M. and Gupta, G.R., 1997, 'Female-headed households and femalemaintained families: are they worth targeting to reduce poverty in developing countries'? Economic Development and Cultural Change 45: 259-280.

Caldwell, J.C., 1978, A theory of fertility: from high plateau to destabilization, Population and Development Review 4: 553-577.

Caldwell, J.C., 1982, Theory of Fertility Decline, Academic Press: London.

Chant, S., 2007, 'Poverty begins at home? Questioning some (mis)conceptions about children, poverty and privation in female-headed households'. UNICEF Report on State of the World's Children 2007, London School of Economics.

Crush, J. (ed.), 2006, States of Vulnerability: The Brain Drain of Future Talent to South Africa, Migration Policy Series No. 42, Southern African Migration Project: Cape Town.

Daily News, 2000, '12,000 illegal immigrants deported', Daily News, 3 February, Gaborone.

Daily News, 2001, 'Illegal immigrants prompt P49 million detention centre', Daily News, 31 October, Gaborone.

Dow, T.E, Archer, L, Khasiani, S. and Kekovole, J., 1994, 'Wealth flow and fertility decline in rural Kenya', 1981-92, Population and Development Review 20: 343-364.

Eloundou-Enyegue, P.M. and Calves, A.E., 2006, 'Till marriage do us part: education and remittances from married women in Africa', Comparative Education Review 50: 1-20.

Fuwa, N., 2000, 'The poverty and heterogeneity among female-headed households revisited: the case of Panama', World Development 28: 1515-1542.

Gaolathe, B., 2007, Budget Speech 2007, Government Printer, Gaborone. 
Gardner, K. and Grillo, R., 2002, 'Transnational households and rituals: an overview', Global Network 2: 179-190.

Gubert, F., 2002, 'Do migrants insure those who stay behind? Evidence from the Kayse area (western Mali)', Oxford Development Studies 30(3): 267-287.

Gwebu, T.D., 2006, 'Towards a theoretical exploration of the differential urbanisation model in sub-Saharan Africa: the Botswana case', Tijdschrift voor Economische en Sociale Geografie 97: 418-433.

Harris, J.R. and Todaro, M.P., 1970, 'Migration, unemployment and development: two-sector analysis', American Economic Review 60: 126-142.

Hosmer, D.W. and Lemeshow, S., 2000, Applied Logistic Regression, New York: Wiley.

Izzard, W., 1985, 'Migrants and mothers: case studies from Botswana', Journal of Southern African Studies 11: 258-280.

Lucas, R.E., 1982, 'Outmigration, remittances and investment in rural areas', in Migration in Botswana: Patterns, Causes and Consequences, National Migration Study, Vol. 3, Government Printers: Gaborone, pp. 627-653.

Lucas, R.E. and Stark, O., 1985, 'Motivations to remit: evidence from Botswana', Journal of Political Economy 93: 901-918.

Maslow, A., 1943, 'A theory of human motivation', Psychology Review 50: 370 396.

Massey, D.S, Arango, J., Hugo, G., Kouaouci, A., Pellegrino, A. and Taylor, J.E., 1993, 'Theories of international migration: a review and appraisal', Population and Development Review 19: 431-466.

Matiage, M., 2002, 'Poverty alleviation through civil society', DPMN Bulletin 9.

Mattes, R, Bratton, M. and Davids, Y.B., 2003, 'Poverty, survival and democracy in southern Africa', Afrobarometer 23, Idasa: Cape Town.

Medeiros, M. and Costa, J.S., 2006, Poverty among Women in Latin America: Feminization or over-representation? Working Paper No. 0020. International Poverty Center: Brasilia.

Mooney, M., 2003, 'Migrants' social ties in the U.S. and investment in Mexico', Social Forces 81: 1147-1170.

Nwoye, A., 2000, 'A framework for intervention in marital conflicts over family finances: a view from Africa', The American Journal of Family Therapy 28: $75-87$.

Portes, A., 1995, 'Economic sociology and the sociology of immigration: a conceptual overview', in The Economic Sociology of Immigration: Essays on Networks, and Entrepreneurship, ed. A. Portes, Russell Sage Foundation: New York, pp. 1-41.

Pregibon, D., 1981, 'Logistic regression diagnostics', The Annals of Statistics 9: 705-724.

Quisumbing, A.R., Haddad, L. and Pena, C., 2001, Are Women Overrepresented among the Poor? An analysis of poverty in ten developing countries, Discussion Paper No. 115, 'Food Consumption and Nutrition Division', International Food Policy Research Institute: Washington, D.C. 
Rempel, H. and Lobdell, R.A.,1978, 'The role of urban-to-rural remittances in rural development', Journal of Development Studies 14: 324-341.

SAMP, 2005, 'Issues in African Migration: South African experiences and attitudes towards migration', Paper presented at the Global Coalition for Africa Policy Forum, Addis Ababa.

Sanni, L., 2006, 'Comparative study of female-headed households in the city of Ibadan', JENDA: A Journal of Culture and African Women Studies 8: 1-14.

Schrieder, G. and Knerr, B., 2000, 'Labour migration as a social security mechanism for smallholder households in Sub-Saharan Africa: the case of Cameroon', Oxford Development Studies 28: 223-237.

Sen, A., 1999, Development as Freedom, Anchor Books: New York.

Shain, Y., 2000, 'The Mexican-American diaspora's impact on Mexico', Political Science Quarterly 114: 661-691.

Stark, O., 1980, 'On the role of urban-to-rural remittances in rural development', Journal of Development Studies 16: 369-374.

Stark, O. and Bloom, D.E., 1985, 'The new economics of labor migration', American Economic Review 75: 173-178.

Stark, O. and Levhari, D., 1982, 'On migration and risk in LDC', Economic Development and Cultural Change 31: 191-196.

Taylor, J.E., 1999, 'The new economics of labour migration and the role of remittances in the migration process', International Migration 37: 63-86.

Todaro, M.P., 1969, 'A model of migration and urban unemployment in less developed countries', American Economic Review 59: 138-148. 
